DOI https://doi.org/10.36059/978-966-397-160-5/50-66

\title{
FUNCTIONAL-SEMANTIC PARAMETRES OF THE GENUINE IMPERATIVE
}

\section{Liubov Umrykhina}

\section{INTRODUCTION}

The imperative as one of the most ancient semantic universals, available in almost every language, is of global importance in human communication. The emergence and active functioning of the imperative is bound by the needs of the social and communicative sphere in establishing interpersonal relationships. Ever since the existence of the ancient linguistic culture, it has served as a communicative means for regulating the behavior of team members consciously coordinating their actions.

The imperative remains an insufficiently studied issue in the modern linguistic science, which is proved by the lack of solved issues regarding the establishment of the boundaries and structure of the categories of the imperative, the contradiction in the defining the central and peripheral zones of semantic expression of the Imperative, the ambiguity of the terminological interpretation of imperative constructions, which are the representatives of the imperative meaning.

The problem of their definition is caused by the multifaceted formation and expression of the imperative modal meaning; by the ability to be fulfilled in multifunctional expressions, reflecting the complex subjective world of the linguistic personality. Nowadays, there is no unanimous opinion among scientists regarding the interpretation of the Imperative.

The ambiguity of views, the inconsistency of interpretations and the heterogeneity of terms regarding the interpretation of the imperative and its grammatical representatives are also present in the Ukrainian linguistics. The study of the imperative is devoted to many modern scientific studios, which in one way or another cover the issues of features of both the structural and grammatical organization of the imperative constructions and the specifics of their communicative implementation. As one of the important tasks, scientists are trying to solve the problem of the genuine imperative, taking into account the various aspects of its study. An analysis of the state of scientific research on the imperative issues indicates the ongoing research process. Therefore, it is relevant to study the imperative modal meaning, 
taking into account the key factors of its formation and expression, functional and semantic specificity of the embodiment of the genuine meaning of the imperative in the Ukrainian language.

The study of the imperative statements, the conditions of their use is important for the communicative aspect. Knowledge of the functioning peculiarities of the imperative constructions is significant not only in grammatical terms, but also in the rules of choosing the socially correct variant, depending on the speech situation, social roles and status of participants in communication.

\section{The essence of the imperative as a subjective-modal meaning}

The imperative as a linguistic phenomenon is closely related to the category of modality, because it represents one of its meanings. The modality of the sentence reflects the extent to which the subject of a speech situation possesses characteristic of a particular feature. First of all, the imperative represents a modality of irreality, since it expresses the situation abstracted from the reality, allowing their mental assumption to replace the reality. The modal subject is the speaker, who is the source of the assessment of the true state of things, who is considering a certain situation as possible and necessary. Therefore, in addition to the meaning of the irreal modality, the imperative also expresses the meaning of the subjective modality.

Adding a «subjective component» to the objective world that is being displayed, causes a picture of reality to be transformed into a virtual plane into a world of subjective perception of a particular situation, which at the moment of speech is fundamentally feasible. Marked by the relatively greater role of the subjective factor, the imperative statements are not merely a statement of a certain irreal situation, but reflect the speaker's intentions to turn the irreality into reality. The speaker tries to implement the situation through his own volition, in other words, it causes the possibility of transforming one state of things into another. "The semantics of the imperative, determined by its functional purpose, reflects an ideal situation of an appealling communication, including the speaker and the listener, and denotes the speaker's will regarding performing an action».

Appealing to a particular addressee, the subject of the volition considers the addressee him as capable of performing the action and thereby contributes to the fulfillment of the fact of reality. The result of the speaker's direct volition, according to his plan, should be the coincidence of the propositional content of his statement with the reality. The use of the imperative to induce the addressee to perform the action referred to, in order to regulate his conduct, is actually, already focused on the potentiality of 
being carried out in the long or short term. The propositional content of the imperative statement is that the addressee will perform an action in the future. Thus, imperative statements express the irreal-potential modal meaning, otherwise, reality in the future, or «future perspective».

The significant semantic component of the imperative is the volationality, a trait related to the speaker's volition, which is to some extent the source of the imperative statement. In general, in the origin of any speech activity is a motive that has an emotional and volitional nature. Human volition is a phenomenon of our language and our linguistic consciousness. The outside world in all its embodiments remains an eternal source of the desires and aspirations of the individual. Each linguistic individual, as the central figure of speech communication, shaping the product of their own mental activity in the form of a fragment of a desirable picture of the world, regulates the process of the information transition from the individual world of feelings and thoughts to the outside - by conveying it through verbalized expression of will. At the same time, the volitional expression involves directed thinking and speech activity of a person, whose activity indicators are a will impulse, motivation, desire, intention and influence on the addressee's conduct. Volition as a compulsory component of the semantics of the imperative captures precisely the situation of volition influence on the part of the speaker to the addressee.

Directing the volition influence of the speaker - the initiator of the transformation of the fragment of reality - on the potential performer of this transformation involves the addressability of the statement. In such a speech interaction, communicative roles are clearly distributed. The speaker, or the subject of the speech, is simultaneously the addressee of the utterance and the causer of the transformation of the true state of things into the desired one. In addition, it is a prescriptor because it influences the interlocutor. The main function of the imperative is not to describe of a certain state of things, behavior or the results of that behavior, but the prescription of that behavior.

An important aspect of addressing of the imperative is the element of active influence on the interlocutor (regardless of the will of the potential performer). «The imperative - predominantly form of order» ${ }^{1}$. Researchers point to the dependence of the prescriptive content of imperative statements on the relationship at the moment of inducement between two persons, the

${ }^{1}$ Benvenist E. (1974) Obshchaya lingvistika [General Linguistics]. Moskva. (in Russian), pp. 308. 
first of which makes the other to perform a causal action ${ }^{2}$. Formation of an imperative content is facilitated by compliance of certain parameters of imperative situation. Notable among these is the credibility of the speaker's position, interested in changing the course of events, related to the addressee's dependent status. Impressive constructions, expressing obligation, are bound to break the boundaries of the independence of the listener.

The genuine imperative is intended to facilitate the fulfillment of the intention, first of all, in the interests of the speaker. The imperative does not indicate the degree of willingness of the potential performer to perform the requested action, does not inform about the presence of the addressee's desire to fulfill the action, about the ability to fulfill it. The imperative indicates, first and foremost, a certain correlation of the imaginary situation with one that could satisfy the needs of the speaker, and therefore seems to him necessary, important, suitable for inducement.

Thus, the imperative is a subjective-modal meaning, the essence of which is an imaginary, but an irreally-potential situation, on the fulfillment of which the speaker emphasizes, causing it as a means of appealing to the addressee. The main structural components of the imperative semantics, which define its specific character, can be considered: the irreality, the potentiality, the volitionality, the addressability, the causality, the prescription. The prescriptive nature of the imperative causes the expression of obligation and necessity. Their expression is facilitated by the maximum controllability of the imperative situation against the background of the high degree of authoritarianism of the speaker, which in the complex creates the preconditions for forcing the listener to perform a causal action.

\section{Specificity of grammatical embodiment of modal meaning of the genuine imperative in the Ukrainian language}

The main grammatical representations of the imperative as modal meaning are the imperative constructions, structural organization of which determines an appropriate modal-oriented potential. Specificity of the imperative construction is its structural and functional-semantic nature. Not every structural model of a sentence forms an imperative form; not every verbal form is capable of performing the prepositional function of the

2 Biryulin L. (1985) Imperativy $\mathrm{v}$ akte rechi [Imperatives in the Speech Act]. Lingvisticheskie issledovaniya. Grammaticheskie kategorii $v$ raznosistemnykh yazykakh. Moskva, pp. 32. 
imperative sentence, and the semantic structure of its propositional concept is always the relation «performer - his action» ${ }^{3}$.

The typical representatives of the main functional-semantic features of the imperative in the Ukrainian language are syntactic constructions with a predicate in the form of a second-person verb in the imperative mood. If linguistic views about the legitimacy of assigning other forms to the sphere of expression of the imperative meaning vary, then the second-person verb form of the imperative, in the opinion of most researchers, is the core of imperativeness in general. Defined as conventional, it is primarily intended to express the prototype inducement. «Since the imperative mood expresses the speaker's appeal to the interlocutor, the most common form of the imperative mood is the second person singular and plural. The meaning of the imperative mood for the first person singular and the third person singular and plural are atypical (typical is the call to the interlocutor)» ${ }^{4}$. Such a concept is a confirmation of the idea of exceptionally direct appeal as the basis for the formation of the imperative, which was expressed long before: «Imperative is a form of direct appeal in which the speaker induces the addressee to the action expressed by the verb. The presence of these two persons (the speaker and the addressee) is the grammatical core, the organizational beginning of the imperative form ${ }^{5}$. The scientists point to the interdependence of the minimal nuclear structure of the appellate act and the relation of the verbal action to the addressee, that is, to the second person: «The semantic structure of the person category in the imperative is formed by the nuclear elementary grammar of the second person and peripheral nonelemental grammars» ${ }^{6}$.

The grammatical features of the verb that indicate the addressee's appeal and its potential action indicate the correlation of a particular form to its original content. Designed to express the direct inducement of the addressee to act on the part of the speaker, the imperative constructions with this predicate are fully consistent with the semantically-functional nature of the genuine imperative.

\footnotetext{
${ }^{3}$ Mikhalkova I. (1986) Imperativnye predlozheniya v sovremennom angliyskom yazyke [Imperative Sentences in Modern English]. Moskva. (in Russian), pp. 4.

${ }^{4}$ Leonova M. (1983) Suchasna ukrayins`ka literaturna mova. Morfologiya [Modern Ukrainian Literary Language. Morphology]. Kyiv, pp. 22.

5 Isachenko A. (1960) Grammaticheskiy stroy russkogo yazyka v sopostavlenii s slovatskim. Morfologiya. [The Grammatical Structure of the Russian Language in Comparison with Slovak. Morphology]. CH. 2. Bratislava. (in Russian), pp. 8.

${ }^{6}$ Dubova O. (2005). Funktsionalne i typolohichne protystavlennia odynyts osobovoi paradyhmy imperatyva [Functional and Typological Juxtaposition of Imperative Personal Paradigm Units]. Linhvistychni doslidzhennia, vol. 16, pp. 12.
} 
In addition, the modal meaning of the imperative is naturally created by infinitive sentences. While syntactic constructions with a predicate in the second person form of the imperative mood verb are determined by the morphological form of the verb according to the categorical meaning of the imperative, one-member sentences with an infinitive predicate are a specialized type of syntactic constructions whose structure is expressive.

The fulfillment of the imperative modal meaning by the means of the independent infinitive is considered a historically determined linguistic phenomenon. Being one of the oldest linguistic forms, the so-called imperative infinitive has its functional-semantic conditionality. Developing on the basis of the verbal noun, the infinitive was entrenched in the verbal system of the Slavic language and was given a specific purpose to express imperative semantics, which is connected with the need to formulate a categorical order. The use of imperative infinitive constructions, which will later be singled out as infinitive sentences, is primarily due to the need to draw up state legal documents. Research on the study of ancient Ukrainian written memorials testifies to the widespread use of infinitive constructs to provide specific guidance on the need and obligation to perform a certain action, a brief and clear list of the responsibilities and rights of a legal entity, and so on.

If in a syntactic construction with the predicate expressed by second person verb the imperative tone dictates the morphological verb form (corresponds the categorical meaning of the mood gram), then one-member sentences with an infinitive predicates are a specialized type of syntactical constructions, the structure of which determines the expression of the imperative. Imperativeness is created by the presence of the infinitive in a predicative basis. The primary function of the infinitive is the expression of the imperative meaning, namely, peremptory order, a positive decree, an order, and sentences with the infinitive predicate are defined as the imperative sentences. The infinitive in the structure of the imperative construction enhances its «voluntary sounding down to the categorical» ${ }^{7}$.

The obligatory semantic components of imperative constructions are the irrevocable volition meaning, the nominal meaning of the action, the meaning of the speaker and the meaning of the addressee, which allows to interpret the meaning of the imperative sentence used as a statement in the sphere of communication like Go! as I command you to go! or You must go!

7 Kharchenko S. (2001) Semantyko-syntaksychna ta komunikatyvna struktura rechen sponukalnoi modalnosti [Semantic-Syntactic and Communicative Structure of Sentences of Incentive Modality], (PhD Thesis). Kyiv: National Pedagogical University of M. P. Dragomanov, pp. 180. 
The mechanism of imperative expression meaning and creating a corresponding imperative effect by means of imperative constructions is based on the dominant semantic feature of obligation, which most clearly appears in the situation of command. After all, the imperative in its primary meaning is intended to express the command, the order. Historically, the functioning of imperative structures as a command was common in the communicative sphere of the representatives of the ruling elite with their subordinates. The authority to command, to order can only be vested in the lord - a person traditionally perceived as commanding, ordering by the right of his power authority, such as: monarch, ruler, prince. Therefore, genetically, the term imperative is associated with the idea of command, order and power authority. The interdependence of the two semantic components of the imperative related to command and authority is also evident, as is enshrined in the definition of the initial lexemes etymologically related to the term «imperative»: imperativus - lat. commanding, imperious, impero - lat. command, rule and imperator - lat. ruler.

In fact, the genuine imperative constructions are the syntactic units that, by conveying the impulse to irrevocable perform of the action, express the meaning of the command, order. Designed in the form of the two types of imperative constructions above, which are suitable for expressing an irrevocable volition, they consolidate the nuclear of the imperative modal meaning.

Accentuating the fact of the irreal situation demanded requires the conciseness and clarity of the expressed opinion. Therefore, genuine imperative constructions differ in the minimized component structure. The classic example of such constructions is one-member, mostly non-extended sentences, in which the predicate accumulates all the imperative force. Given with a powerful imperative charge, they show informative sufficiency, fully consistent with the pragmatic intentions of the speaker: to induce a certain action, focusing on the procedural attribute that should be realized. The morphological representative of the predicate in the structure of the imperative constructions is predominantly verbs denoting active, dynamic, purposeful action. The semantic volume of the verb in which the predicate is expressed is the focal point that directs the relationship between the speaker and the addressee. The specific action, expressed in the propositional form, is perceived and realized by the addressee. The imperative statement is a mediator between the mental action of the speaker and the irreal-potential action of the addressee.

Despite the inherent attachment of the genuine imperative construction to the semantic subject, the grammatical expression of it is usually offset, 
especially in the case of infinitive sentences. In the foreground, there is the significance of the fact of the potential performed action, the necessity of which is obvious to the subject of the message. The potentiality of the realization of the demanded situation is beyond doubt, in the opinion of the speaker, and moreover, in his own interpretation it is obligatory for the addressee. At the same time, his physical ability and moral readiness to obey the order remain beyond the subjective perception of the speaker.

Carrying the seal of power and representing the utmost irrevocable genuine imperative constructions genetically reduce the level of individual status of the interlocutor, depriving him of his own right to decide the fate of the future situation, which also applies directly to his personality. Using such a rigid form of volition, the speaker places himself above the other party, lowering him in status. Therefore, the modern communicator resorts to extending the structure of the imperative constructions itself by introducing the vocative or the subjective pronoun to identify the subject of action, which is impossible in the case of infinitive sentences, structurally devoid of the ability to mitigate the rigidity of the imperative through the introduction of markers of respectful attitude toward the addressee.

Thus, the imperative, as a subjective-modal meaning, finds the maximum embodiments of its genuine characteristics in the infinitive and the second person form verb of the imperative mood, which form the predicative center of genuine imperative constructions. This grammatical form of implementation of the imperative corresponds to the specific character of fulfillment of the most irrevocable volition, which is the command and order.

\section{Basic functional-semantic types of the genuine imperative constructions (in the Ukrainian language)}

The genuine imperative constructions function in the following basic ways: the command, the military order, the military command, the emergency command, the educational-pedagogical command, the household command.

Commands belong to the sphere of a direct suggestive influence because they require a quick and accurate performance without criticism of consciousness. It is a special kind of verbal action, the implementation of which is largely determined by the social traditions of communicative interaction.

An imperative utterance becomes meaningful to the command when the speaker gives the addressee the status of the object of influence, not entirely free causal action subject. It is facilitated, first of all, by the objective 
circumstances surrounding the social inequality of the communicators and, consequently, the vertical nature of their relationship. The command is always directed from the top down, from the highest status to the lower status, such as, in particular, the lord and subordinate.

Given the social statuses of the lord and the subordinate implementation of the command, it is obligatory for the addressee, although it may not be very advantageous and desirable for him. In this case, the representative of the elite class does not take into consideration the feeling of the subordinate, considering him only as the subject of fulfillment of the demanded situation. The addressee is convinced that he has the right to insist on the actions, s/he is sure that the addressee is able to do so. The less the speaker respects the free will of the addressee, the less he perceives it as a free, autonomous personality.

A verbal response to this type of appeal is not relevant under the rules of the command - obedience scenario, which itself eliminates dialogism. Numerous life examples of the imperative constructions of the command functioning indicate an instant required reaction of the addressee. An analysis of the examples proves the validity of the listener's positive response to the impulse received in terms of the implementation of the required situation, which seems obvious and predictable, since it is quite adequate for such a communicative situation.

Due to its high social status and communicative preference, the speaker is able to impose their will to the listener who is forced to obey and perform the actions expected of there.

The historically determined change in the social roles of participants in communication has devalued the communicative value and relevance of such a categorical form of volition, as the command, which in the modern world of interaction requires the correction of speech behavior in order to show respect for the addressee's personal space.

The relevant communicative space for the operation of genuine imperative structures is the military speech sphere, where they appear in the role of the military order. An important factor in implementation is the communicative consistency between its participants: the addressee voluntarily accepts the role of the active listener and immediately confirms his willingness to be an active performer. This is facilitated in advance by «through any prior procedure, either spoken or unspoken», the position of acceptance of the addressee's authority and absolute confidence in their speech behavior on the part of the addressee ${ }^{8}$, because it is the will of the

\footnotetext{
${ }^{8}$ Ostin Dzh. (1986). Slovo kak deystvie. [Word as Action] Novoe v zarubezhnoy lingvistike, vol. 17. Moskva, pp. 41.
} 
volitioner who is responsible for the correctness of the chosen decision to implement a specific situation. The distribution of the communicative roles of the participants of the order - the obedience scenario correlates with the subordinate relations between them established and adopted in accordance with the rules of the military statute.

The objective need of maximum readiness for emergency tasks determines the choice of language formulas required for an instant response that would convey the content of the message in a short and clear form. The inducing potential of imperative constructions contributes to the creation of the desired communicative effect. Expressed briefly, clearly and powerfully, these units are best suited for the purpose of their application, which is related to the required result of an alternative and rapid implementation of a particular situation.

In the military language there is a whole set of imperative constructions for expressing the command clearly stated in the charter. These are laconic cliché language formulas, structured using genuine imperative constructions, which are used to perform an imperative signal for the immediate implementation of a specific physical action. The imperative constructions of the command are a specific kind of verbal influence, which has a suggestive character, since it requires instant subconscious mobilization of the body to any action. The command is focused on an immediate and accurate activity response as a result of the formed skill of automatically perceiving the usual verbal stimulus in the observance of military norms.

It is important to take into account the fact of communicative consistency between the participants of the received dialogue. The recipient voluntarily accepts the role of active listener and immediately confirms their willingness to be an active performer. A favorable condition for such success is interpersonal relationships of the communicators established in accordance with the rules of military subordination.

The peculiarity of the syntactic type of imperative constructions, which are suitable for expressing the command, is that the singular form of the verb, in which the predicate is expressed, is able to convey addressability of the action to one person and to a group of peoples. In this case, the ability of a single verb form to denote the plurality of potential figures is justified by the interconnectedness with a touch of «collectiveness»: the commands given do not refer to each soldier individually but to the whole group.

The genuine imperative constructions in the function of the military orders and commands are also not quite standard in the field of military affairs. It is a matter of applying the binding potential of these structures to the dominant from the standpoint of physical force, not status, by the party 
for the purpose of hard, brute pressure on the enslaved person. In this case, the acceptance of the irrevocable authority of the speaker by the addressee as a prerequisite for the implementation of imperative constructions of the order is replaced by a sense of instinctive self-preservation, which forces the addressee to obey the will of the sender of the imperative statement. Thus, there is a critical violation of the conventional norms of military communicative ethics, in which a situational dominant individual, by virtue of artificial social advantage, actually commits speech violence against the addressee. Such communicative deviance is clearly illustrated by examples - captive», «warden - prisoner». The use of a rigid form of categorical volition, representing genuine imperative constructions, in the conditions of gross moral and physical domination of the speaker over the addressee can be regarded as a deviation from the norm.

The genuine imperative constructions function to express emergency inducement for the fulfillment of a certain situation, the urgency of which is caused by the extraordinary circumstances of life, which requires immediate and extremely urgent perception of the verbal signal and the implementation of action.

The need for maximum time savings also requires cost savings in language. The imperative constructions used in an emergency situation, which requires urgent decision making in the conditions of excessive emotional stress, are distinguished by the particular brevity of the stated idea, embodied in speech by means of minimization of grammatical composition. Created spontaneously, often formed on an automatic, even uncontrollable, subconsciously, they represent the impulsive nature of speech action, in comparison to the order - an indicator of a fully thought out intention of the addressee.

The genuine imperative constructions that function as non-military emergency commands can convey an appeal to a group of recipients whom the speaker perceives as a whole. This explains the usage in singular constructions of the singular form of the verb predicate to define the plural. The genuine imperative constructions of emergency commands can also relate to the individual of the addressee.

The suddenness of unforeseen communication provokes an invective connotation of statements that attests to the impulsiveness of the emergence of genuine imperative constructions of emergency orders, suitable for emergency response in non-military situations. 
The genuine imperative constructions are used to express the command in the educational-pedagogical sphere. Participants in the communicative act in which they are implemented are, in particular, a subordinate antonymic of each other teacher and student. Accepting the authority of a person's senior social status in this case is an irrevocable rule of the student's moral behavior. In contrast to the military front of speech actions, the educationalpedagogical field does not propose a fixed list of the basic commands for the study and further implementation of the wards. There is an automatic perception of verbalized stimulus actions as an impulse to act responsibly at a subconscious, intuitive level.

The educational-pedagogical commands belong to speech actions of direct pedagogical influence, which perform a peculiar signal function for instantaneous mobilization of the organism in the direction of carrying out the required act of action. They are an important means of disciplining students and contribute to improving the aesthetics of the children's collective.

The genuine imperative constructions representing mainly short completed statements of the educational-pedagogical commands, for example, Sit!; Stand up straight!; Look at the board!; Open the notebook!; Raise your hands!; Make a note of the diary!; Remove the tutorials from the table!, perform the tasks that are part of the customary ritual formulas. Accompanying the daily speech activity of the speaker-teacher, they are an integral part of the normal educational process and do not cause problems with the adequacy of interpretation of the spoken.

Despite the uniformity and clichéd nature of such imperative constructions, they can reform the semantic-syntactic structure to reduce the rigidity degree of the educational-pedagogical commands, for example, Please raise your hands!, which is unacceptable, in contrast, in the military sphere.

As a permanent component of educational-pedagogical communication, imperative constructions can be used to stimulate not only the immediate physical response, but also to activate the mental activity of students. In this case, they induce a certain mental action: Pay attention!; Think about it!; Listen!; Remember!; Think about it!; Find out!.

Numerous similar commands have moved into the sphere of written language, becoming an accessible and familiar form of transferring the content of a study assignment, such as: Give an example; Give a definition; Edit the text; Explain spelling of punctuation; Make up the sentence; Find 
the right answer; Read the poem; Rewrite the words; Insert punctuation marks.

In the educational-pedagogical sphere, there are the genuine imperative constructions-clichés, implemented in the functions of sport order, identical with the genuine imperative constructions of the command, used in the military sphere. They are used not only in physical education lessons but also in the broader educational practice. The orders transmitted by means of imperative constructions, such as: Form to ranks!; Change step!; Turn around!; Fall out!; Fall in!; Come on out!, designed for automatic response and irrevocable implementation.

The high degree of perfection of the action is determined by the regularity of the use of such imperative constructions in standard communication situations. Similar to the military commands, such training commands are expressed only in the form of fundamentally immutable clichéd imperative constructions with a well-defined internal structure that blocks any variability in form and flexibility of content.

The household sphere is also an active producer of the genuine imperative constructions of the command. In different circumstances, it may be necessary to form the imperative statement as a guiding signal to quickly stimulate the addressee to perform a specific physical action. A necessary basis for the realization of this speech phenomenon is the correspondence of the interpersonal parameters of the communicative situation, in which the degree of communication strength between the speaker and the addressee, which would provide a sufficient level of trust in each other to be able to send and receive such communication, should be sufficiently high.

In the conditions of deviant social interaction, which is characterized by a severe violation of personal rights, there is a tendency to actively using the genuine imperative constructions of the order, command by the dominant (from the standpoint of physical force) party, which manifests a negligent attitude to the addressee moral humiliation.

Despite the extreme effectiveness of the genuine imperative constructions in terms of expressing the content of the volition, it is socially known today that the use of such markers of an imperative rigidity is inappropriate. The modern world of communication requires a new model of speech behavior, completely devoid of the imperial communication features.

In modern communication, the addressee must into account the social and etiquette side of the utterance; take into account the free will of the addressee, showing respect for the interlocutor. In some communicative 
cultures, there are unspoken communicative rules regarding the exclusion of genuine imperative constructions in speech, because these constructions are considered a provocative invasion of personal space.

Scientists point to the law of effectiveness of communicative effort: the effectiveness of communication is directly proportional to communicative effort. That is, the more communicative effort the addressee consumes, the higher the effectiveness of his speech influence. Effective communication differs in maximizing costs: to achieve communicative success, it is necessary to apply the whole arsenal of verbal and non-verbal means, obey the laws, rules, conventions of communication, etiquette rules, etc., that is, to spend more effort. Brief statements are generally perceived as impolite, aggressive ${ }^{9}$.

The research opens the prospects of exploring ways to reduce the imperative pressure on the addressee in order to improving the modern communicative culture.

\section{CONCLUSIONS}

The semantics of the genuine imperative constructions are determined by their specific functional purpose, which is to induce a high degree of categoricalness to the irrevocable implementation the action. By expressing the command and order, they consolidate the core of the imperative and form the central functional-semantic type of imperative structures, the distinctive feature of which is the binding nature of the causal action. Among all types of the imperative constructions, they exhibit the highest level of voluntary pressure on the potential subject to perform the required action.

The genuine imperative constructions are structured mainly by onemember sentences with a predicate in the form of a second-person imperative mood verb and one-member sentences with an infinitive predicate (in the Ukrainian language). The infinitive sentences are a specialized type of syntactic constructions intended to embody imperative modality.

The genuine imperative constructions function in the following basic ways: the command, the military order, the military command, the emergency command, the educational-pedagogical command and the household command.

9 Batsevych F. (2009) Osnovy komunikatyvnoi linhvistyky [Fundamentals of Communicative Linguistics]. Kyiv. (in Ukrainian), pp. 43-44. 
Significant constituents of the imperative semantics of this type of constructions is the necessity, the formation of which is facilitated by such basic parameters as the authority of the speaker and the controllability of the situation, the activation of which is provided by the special conditions of the communicative situation under which circumstances each particular kind of meaning is realized.

The expression of the command ensures the correspondence of the speaker's authoritarianism and the actual non-availability of the addressee, which is possible with the rigid social status differentiation of the communicants; military order and command - voluntary acceptance of the addressee's authority by the addressee in terms of established military subordination; educational-pedagogical command - genetic adherence to the addressee's norms of status subordination, embedded in the atmosphere of subconscious acceptance of parental authority; the household command accepting the authority of the addressee according to the interpersonal interaction of the communicators. The implementation of an emergency command is distinguished by the impulsive nature of the speech action, caused by the unpredictability of a sudden emotional situation.

The use of a rigid form of the categorical expression of volition in conditions of gross moral and physical dominance of the speaker over the addressee is regarded as a deviation from the norm. The prospect for further research is the analysis of the means of reducing the categorical volition in the content of genuine imperative constructions in order to correct the speech behavior of the modern speaker.

\section{SUMMARY}

The article deals with analysis of the semantic structure of the central type of the imperative constructions (based on the Ukrainian language), the main informative parameters of the imperative in the functioning of the genuine imperative construction are pointed out. The definition of structural and grammatical center of forming the genuine imperative structures is commented on.

The author focuses on the interdependence of their semantics and the specifics of the functional purpose - high categorical inducement for the irrevocable performance of the action. The dominant components of the content structure of the imperative constructions are determined, as well as important signs of the communicative sphere that influence the implementation of the genuine imperative meaning, such as: the irreality, the 
potentiality, the volitionality, the addressability, the causality, the prescription, and, in addition, the necessity, the obligation.

The author categorized and described the main functional-semantic types of the imperative constructions, such as: the command, the military order, the military command, the emergency command, the educationalpedagogical command and the household command. The semantic nuances of them and their differential factors of formation are commented on.

It is confirmed that genuine imperative constructions, being the functional-semantic core of the expression of the imperative modal meaning, express the most severe impulse to action.

The prospects for further research of the imperative and the genuine imperative constructions are outlined.

\section{REFERENCES}

1. Batsevych F. (2009) Osnovy komunikatyvnoi linhvistyky [Fundamentals of Communicative Linguistics]. Kyiv. (in Ukrainian)

2. Benvenist E. (1974) Obshchaya lingvistika [General Linguistics]. Moskva. (in Russian)

3. Biryulin L. (1985) Imperativy v akte rechi [Imperatives in the Speech Act]. Lingvisticheskie issledovaniya. Grammaticheskie kategorii $v$ raznosistemnykh yazykakh. Moskva. pp. 28-36

4. Bondarko A. (1990) Teoriya funktsional'noy grammatiki. Temporal'nost'. Modal'nost' [Theory of Functional Grammar. Temporality. Modality] Leningrad. (in Russian).

5. Daskaliuk O. (2006). Semantyko-hramatychna kharakterystyka imperatyva suchasnoi ukrainskoi movy [Semantic and Grammatical cCaracteristics of the Imperative of Modern Ukrainian], (PhD Thesis). Chernivtsi: Chernivetsk National University of Yuriy Fedkovich.

6. Dubova O. (2005). Funktsionalne i typolohichne protystavlennia odynyts osobovoi paradyhmy imperatyva [Functional and Typological Juxtaposition of Imperative Personal Paradigm Units]. Linhvistychni doslidzhennia, vol. 16. pp.11-16.

7. Gusev V. (2013). Tipologiya imperativa [Typology of Imperative]. Moskva. (in Russian)

8. Isachenko A. (1960) Grammaticheskiy stroy russkogo yazyka v sopostavlenii s slovatskim. Morfologiya. [The Grammatical Structure of the Russian Language in Comparison with Slovak. Morphology]. CH. 2. Bratislava. (in Russian) 
9. Kharchenko S. (2001) Semantyko-syntaksychna ta komunikatyvna struktura rechen sponukalnoi modalnosti [Semantic-Syntactic and Communicative Structure of Sentences of Incentive Modality], (PhD Thesis). Kyiv: National Pedagogical University of M. P. Dragomanov.

10.Leonova M. (1983) Suchasna ukrayins`ka literaturna mova. Morfologiya [Modern Ukrainian Literary Language. Morphology]. Kyiv.

11. Mikhalkova I. (1986) Imperativnye predlozheniya v sovremennom angliyskom yazyke [Imperative Sentences in Modern English]. Moskva. (in Russian)

12. Ostin Dzh. (1986). Slovo kak deystvie. [Word as Action] Novoe v zarubezhnoy lingvistike, vol.17. Moskva. pp. 22-130.

\section{Information about the author:}

Liubov Umrykhina,

$\mathrm{PhD}$ in Philology, Doctoral Student, H. S. Skovoroda Kharkiv National Pedagogikal University 2, Valentynivska str., Kharkiv, 61168, Ukraine ORCID ID: orcid.org/0000-0003-3888-342X 